\title{
21. RADIOCARBON DATING OF RECENT SEDIMENTS FROM LEG 64, GULF OF CALIFORNIA ${ }^{1}$
}

\author{
Elliott C. Spiker, U.S. Geological Survey, Reston, Virginia \\ and
}

B. R. T. Simoneit, ${ }^{2}$ Institute of Geophysics and Planetary Physics,

University of California-Los Angeles, Los Angeles, California

\begin{abstract}
Samples from Sites $474,476-479$, and 481 have been dated by the radiocarbon method to $>40,000 \mathrm{y}$. Most of the late Wisconsinan to Holocene sedimentation rates were much greater than those estimated from biostratigraphy for Quaternary sediments deposited before 40,000 y. ago, being highest in the Guaymas Basin (rate at Site $477>$ rate at Site $481>$ rate at Site 478), intermediate at the mouth of the Gulf of California (rate at Site $476>$ rate at Site 474 ), and lowest on the Guaymas slope. ${ }^{3}$
\end{abstract}

\section{INTRODUCTION}

Quaternary sediment accumulation rates in the Gulf of California were estimated from the biostratigraphic record (Curray et al., 1979). We were, therefore, interested in applying radiocarbon dating to the shallower sedimentary sequences to supplement the age data from biostratigraphy.

\section{METHODS}

Short sections of core material were sampled aboard ship, frozen in Kapak bags, and stored to await analysis. Depending on sample size and carbon content, radiocarbon measurements were performed on the carbonate fraction or the organic carbon fraction. The carbonate carbon was extracted by leaching with dilute $\mathrm{HCl}$ in a vacuum system. The residual sample material was filtered, washed, and dried. Next, the organic carbon was extracted by combustion in a vacuum. The ${ }^{14} \mathrm{C}$ activity was analyzed by the acetylene gas-counting method (modified from the method described by Suess, 1954) at the U.S. Geological Survey, Reston, Virginia. Sample activities have not been corrected for isotope fractionation by a ${ }^{13} \mathrm{C}$ measurement. If $\delta^{13} \mathrm{C}$ values are assumed to be zero for the carbonate and $-21 \%$ for the organic fractions, this correction would add approximately $412 \mathrm{y}$. to each date derived from carbonate carbon and $65 \mathrm{y}$. to each date derived from organic carbon. The true age, however, may be as much as $1000 \mathrm{y}$. younger than this corrected value, because reworked material may be incorporated in the samples and because of the marine-reservoir effect (the radiocarbon deficiency of ocean waters; Broecker et al., 1960). The dates given in Table 1 were calculated relative to the U.S. National Bureau of Standards oxalic-acid standard activity (Stuiver and Polach, 1977).

\section{RESULTS AND DISCUSSION}

The radiocarbon data for the organic and the carbonate carbon fractions of the samples are found in Table 1, and the results are plotted in Figure 1. We do not know why the ages of these two fractions appear to differ somewhat. Table 2 is a comparison of the approximate sedimentation rates for the upper section of each hole

\footnotetext{
${ }^{1}$ Curray, J. R., Moore, D. G., et al., Init. Repts. DSDP, 64: Washington (U.S. Govt. Printing Office).

${ }_{3}^{2}$ Present address: School of Oceanography, Oregon State University, Corvallis, Oregon. ${ }^{3}$ After submission of this manuscript, all estimates of rates of accumulation were revised from those of the Geotimes article (Curray et al., 1979) by addition of new data. See site chapters (this volume, Pt. 1), Aubry et al. (this volume, Pt. 2), and Curray et al. (this volume, $\mathrm{Pt}$. 2). The conclusion is, however, the same, that radiocarbon dating yields much higher estimates of rates of accumulation than biostratigraphic data.
}

Table 1. Radiocarbon dating of sediments from the Gulf of California Leg 64 .

\begin{tabular}{lccc}
\hline & & \multicolumn{2}{c}{ Radiocarbon Dates } \\
\cline { 3 - 4 } \multicolumn{1}{c}{$\begin{array}{c}\text { Sample } \\
\text { (interval in cm) }\end{array}$} & $\begin{array}{c}\text { Sub-bottom } \\
\text { Depth } \\
(\mathrm{m})\end{array}$ & $\begin{array}{c}\text { Organic } \\
\text { Carbon }\end{array}$ & $\begin{array}{c}\text { Carbonate } \\
\text { Carbon }\end{array}$ \\
$474-5-3,115-120$ & $34.65(38.25)$ & $34,200 \pm 1500$ & $26,400 \pm 800$ \\
$476-2-2,73-79$ & $11.23(13.8)$ & $>40,000$ & - \\
$476-7-2,113-117$ & $59.13(59.1)$ & - & $30,650 \pm 1200$ \\
$477-3-1,135-140$ & $11.85(19.15)$ & $2,710 \pm 110$ & - \\
$477-4-1,145-150$ & $21.45(29.2)$ & $5,660 \pm 80$ & $8,020 \pm 230$ \\
$477-5-1,115-120$ & $30.65(37.0)$ & $5,350 \pm 100$ & - \\
$477-17-1,140-145$ & $125.9(131.3)$ & - & - \\
$478-2-1,7-18$ & $3.57(4.27)$ & $3,420 \pm 210$ & - \\
$478-2-4,102-113$ & $9.02(9.72)$ & - & - \\
$478-2-5,49-55$ & $11.0(11.7)$ & - & - \\
$479-1-2,37-42$ & $1.87(2.4)$ & $4,540 \pm 120$ & - \\
$479-3-1,67-74$ & $13.17(18.3)$ & $16,820 \pm 340$ & - \\
$479-6-1,16-25$ & $41.16(42.55)$ & - & - \\
$481-3-2,31-46$ & $11.31(11.65)$ & $7,950 \pm 100$ & - \\
$481-10-2,45-55$ & $44.70(44.7)$ & $4,490 \pm 110$ & - \\
\hline
\end{tabular}

Note: Dash indicates insufficient carbon for dating.

a Depth from top of core downward; figure in parentheses is the distance from core catcher upward.

b Dates are given as years before present, referenced to the year 1950.

with data based on the biostratigraphic record described in the literature.

\section{Mouth of the Gulf}

Only limited data are available for Sites 474 and 476, which are at the mouth of the Gulf. The average sedimentation rate calculated from radiocarbon ages for Site 474 is $120 \mathrm{~cm} / 10^{3} \mathrm{y}$. - about five times larger than the estimate from biostratigraphy. At Site 476, the shallow sample is anomalously old; possibly it contains recycled, geologically old organic matter. The average sedimentation rate calculated from radiocarbon ages is $192 \mathrm{~cm} / 10^{3} \mathrm{y}$. which is about double the biostratigraphic estimate.

\section{Guaymas Basin}

The ${ }^{14} \mathrm{C}$ data for the Guaymas Basin sites $(477,478$, 481 ) are limited yet complicated (Table 1). The complex 


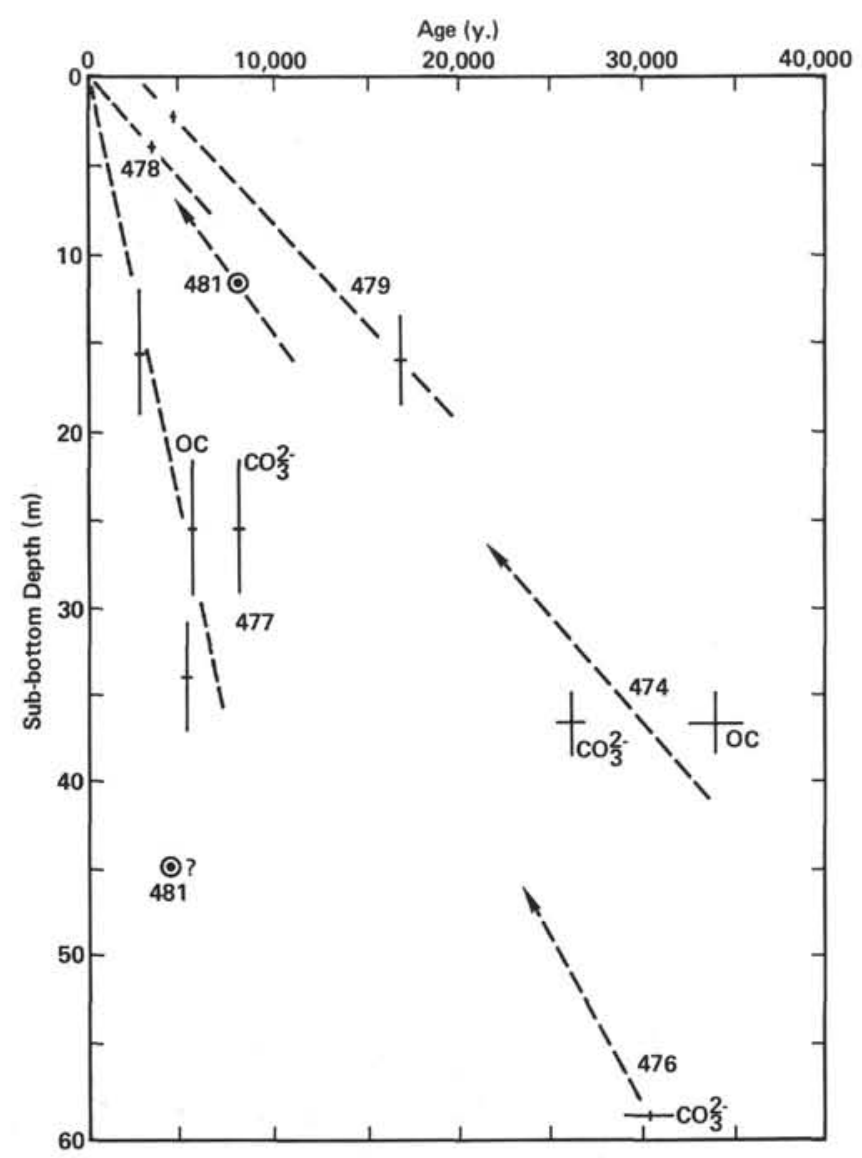

Figure 1. Radiocarbon age versus sub-bottom depth for core samples from Leg 64 Sites 474, 476-479, and 481. (OC = organic carbon; $\mathrm{CO}_{3}^{2-}=$ carbonate carbon).

Table 2. Comparative sedimentation rates.

\begin{tabular}{|c|c|c|}
\hline \multirow[b]{2}{*}{ Site } & \multicolumn{2}{|c|}{ Sedimentation Rates $\left(\mathrm{cm} / 10^{3} \mathrm{y}\right.$.) } \\
\hline & $\begin{array}{c}\text { Based on } \\
\text { Radiocarbon Ages }\end{array}$ & $\begin{array}{c}\text { Biostratigraphic } \\
\text { Record and } \\
\text { Literature }\end{array}$ \\
\hline 474 & 120 & $24^{b}$ \\
\hline 476 & 192 & $80^{\mathrm{b}}$ \\
\hline 477 & 480 & $\begin{aligned} &> 120^{\mathrm{b}} \\
& 100^{\mathrm{c}}\end{aligned}$ \\
\hline 478 & 92 & $>120^{\mathrm{b}}$ \\
\hline 479 & $112(96)^{\mathrm{a}}$ & $50^{\mathrm{b}}$ \\
\hline 481 & 144 & $>120^{\mathrm{b}}$ \\
\hline
\end{tabular}

tectonic history of the basin may account for the younger material below the older material at Sites 477 and 481, possibly brought in by slumping. The average sedimentation rates calculated from radiocarbon ages are 480 $\mathrm{cm} / 10^{3} \mathrm{y}$. for Site 477 and $144 \mathrm{~cm} / 10^{3} \mathrm{y}$. for Site 481 . The rate for Site 477 is as much as five times the estimate derived from biostratigraphy. At Site 478, the two sedimentation-rate estimates are in relatively good agreement-approximately $100 \mathrm{~cm} / 10^{3} \mathrm{y}$.

\section{Guaymas Slope}

Only two values could be obtained from the Guaymas Slope samples (Site 479; Table 1), and the intercept of the extrapolation to the seabed yields an apparent age of about $2600 \mathrm{y}$. for the organic matter. Similarly apparent ages (about 2500 y.) for seabed organic matter have been observed in the Southern California Bight (Emery and Bray, 1962). These old seabed ages are probably explained by sediment mixing and the incorporation of older, reworked carbon. The average sedimentation rate calculated from radiocarbon dates is $112 \mathrm{~cm} /$ $10^{3} \mathrm{y}$., which is about double the estimate from biostratigraphy.

The sedimentation rates calculated from radiocarbon ages for Sites 474, 476-479, and 481 (Table 2) are greater than the Cariaco Trench mean rate of $50 \mathrm{~cm} / 10^{3} \mathrm{y}$. (Spiker and Simoneit, 1980).

\section{CONCLUSIONS}

Samples from Sites $474,476-479$, and 481 have been dated by the radiocarbon method to $>40,000 \mathrm{y}$. at subbottom depths to about 60 meters. Most of the sedimentation rates calculated from radiocarbon ages were much greater than those estimated from the biostratigraphic record, suggesting that either the rates have increased significantly in the late Pleistocene or Holocene or that the samples are contaminated with young carbon. The apparent rates of accumulation are highest in the Guaymas Basin (rate at Site $477>$ rate at Site $481>$ rate at Site 478), are intermediate at the Mouth of the Gulf (rate at Sites $476>$ rate at Site 474 ), and are lowest on the Guaymas Slope.

\section{ACKNOWLEDGMENT}

We thank Meyer Rubin and Thomas M. Cronin for reviewing this manuscript. Contribution 2107, Institute of Geophysics and Planetary Physics, UCLA. Any use of trade names is for descriptive purposes only and does not constitute endorsement by the U.S. Geological Survey.

\section{REFERENCES}

Broecker, W., Gerard, R., Ewing, M., et al., 1960. Natural radiocarbon in the Atlantic Ocean. J. Geophys. Res., 65:2903-2931.

Calvert, S. E., 1966. Accumulation of diatomaceous silica in the sediments of the Gulf of California. Geol. Soc. Am. Bull., 77:569596.

Curray, J. R., Moore, D. G., Aguayo, J. E., et al. 1979. In the Gulf of California Leg 64 seeks evidence on development of basins. Geotimes, 24(7):18-20.

Emery, K. O., and Bray, E. E., 1962. Radiocarbon dating of California Basin sediments. Am. Assoc. Pet. Geol. Bull., 46:1839-1956.

Spiker, E., and Simoneit, B. R. T., in press. Radiocarbon dating of sediments from the Cariaco Trench DSDP Site 147. In Moore, C., Watkins, J. S., et al., Init. Repts. DSDP, 66: Washington (U.S. Govt. Printing Office).

Stuiver, M., and Polach, H. A., 1977. Reporting of ${ }^{14} \mathrm{C}$ data. Radiocarbon, 19:355-363.

Suess, H. E., 1954. Natural radiocarbon measurements by acetylene counting. Science, 120:5-7.

van Andel, Tj. H., 1964. Recent marine sediments of Gulf of California. In van Andel, Tj. H., and Shor, G. G. (Eds.), Marine Geology of the Gulf of the Gulf of California: A Symposium: Tulsa (American Association of Petroleum Geologists), pp. 216-310. 